\title{
Perception of Brazilian Consumers about Sustainable Food Packaging
}

\author{
Lívia de Souza Alexandre ${ }^{1}$, Anderson Marcolino Pereira de Oliveira ${ }^{2}$, \\ Walkyria Carvalho ${ }^{3}$ \\ 1,2,3 Master Student in Sustainable Local Development Management \\ University of Pernambuco, Brazil
}

\begin{abstract}
With the increase of support for sustainability by the population, it was noticed the interest for the sustainable packages. Therefore, the researchers focused on how to increase the sustainability of packaging through the use of eco-design tools, however, previous studies have not yet investigated the relationship between sustainable packaging and consumer behavior during the purchase and recycling of the life cycle of the packaging, which would facilitate the development of a product more directed to the interests of the final consumer. The present study aims to examine the importance that Brazilian consumers give to sustainable packaging during the decision to purchase similar products. This research was carried out with 2,893 people in Brazil, who answered an online form. Based on the responses, two groups of consumers were identified: a group that attributes importance to sustainable packaging and another that considers these packaging unimportant in the decisions to purchase products. Based on the results obtained, it was seen that gender, environmental awareness, concerns about the opinions of society, positive attitude towards green purchasing and the perception of consumer actions are factors that differentiate the two groups of consumers. The findings of this study should be relevant to public decision makers, packaging companies, and marketers.
\end{abstract}

Keywords: consumption profile, footprint, packaging, sustainable consumption, sustainable economy.

\section{Introduction}

Food packaging technology aims at balancing their protection, taking into account not only the simple fact of physically protecting food, but other issues, such as energy and material costs, greater socio-environmental awareness, and regulations on pollutants and solid waste disposal. The Environmental Protection Agency of the United States (EPA) found that approximately 31 percent of urban solid waste generated in 2005 was from packaging materials including glass, metal, plastic, paper and cardboard, and that percentage remained relatively constant since the 1990s, despite an increase in the total amount of urban solid waste (Marsh \& Bugusu, 2007). 
Studies show that the environmental impacts of packaging are as important as that of the food they contain (Grau, 2015). In addition, it is commonly said that the most significant task of the package is to protect the product, so it is important to know the packaging design process in order to make the main function of it less harmful to the environment. Then the entire product-package combination life cycle is taken into account. The emphasis should be on the prevention of food losses, as well as simply protecting it, in packaging design as an important environmental criterion. Consideration of the properties of the package and of the product itself when designing the final enclosure will lead to a better final result, with lower product losses and environmental impacts. By using different evaluation methods in the diversified stages of packaging design, the sustainability of the package can be improved, since the objective is to integrate sustainability aspects at all stages with firmness in the design process, a preponderant element in the perception of consumers of its products.

From this point of view, the consumer society is characterized by the relations of consumption and associated values, which would be conditioned to the production of goods and services, so it was possible to conclude about this that social success and personal happiness are identified by the level of consumption that the individual has (Betts, 2004). Overestimating the undeniable hegemony of the ideology of consumption may lead one to lose sight of the other problems of our society, for example, to fail to understand that consumption only exists because of the current great production of goods (Fontoura et al., 2018).

Packaging plays a key role in ensuring the safe delivery of goods throughout the supply chain to the end consumer. It also has great potential to contribute to sustainable development. Therefore, this article explores and provides insight into the perceptions of Brazilian consumers and knowledge of the environmental aspects of food packaging. Paper packaging is strongly understood by consumers surveyed as environmentally advantageous, while plastics and metals do not. This study also indicates that a minority of the Brazilian consumers interviewed are aware of their deficiencies in judging the environmental status of food packaging, indicating the need for guidance; otherwise, consumer choices can intentionally counteract choices that are not environmentally sustainable.

Due to a growing appreciation of sustainability as a whole, food packaging technology is continuously evolving. Proof of this is active packaging, which proves to be an innovative approach to improving the shelf life of food, improving its quality, safety and integrity. An example of this is the use of chitosan, which is a deacetylated chitin derivative, which is the second most abundant polysaccharide found in nature after cellulose (Nowzari et al., 2013). Chitosan is non-toxic, biocompatible and biodegradable and is therefore considered to be environmentally friendly packaging material. In addition, chitosan is a good inhibitor against the growth of a wide variety of yeasts, fungi and bacteria, and also exhibits barrier properties to gases and flavors under dry conditions. Along with these features, its ease in forming films makes it an interesting choice for active antimicrobial food packaging applications. 
Another evolution of food packaging technology was the incorporation of antioxidant and antimicrobial agents into edible films. For environmental reasons, it is increasingly desirable that at least packaging be biodegradable and, where possible, obtained from low-cost sustainable resources (Mohebi \& Shahbazi). Biopolymers from which edible films are made have been extensively investigated in the last two decades because they can be a viable solution for the disposal of residues of plastic packaging materials from food (Nitschke et al., 2011).

Active packaging involves the interaction between the package, the product and the environment in order to extend the useful life of the product or increase its safety while maintaining its nutritional quality. One class of active packages are antimicrobial packages used to reduce the growth rate and limit the maximum population of microorganisms. Antimicrobial packaging materials must be in direct contact with the surface of the food if they are not volatile and can be immobilized on the surface of the material or able to migrate to the food. Therefore, antimicrobial packaging is effective in food products where microbial contamination occurs on the surface (Realini \& Marcos, 2014).

Packaging films incorporated with antimicrobial substances have great potential for food preservation because of their antiseptic properties (Huang et al., 2012). This type of material is considered one of the most promising active packaging systems because it is highly effective in killing or inhibiting spoiled and pathogenic microorganisms that contaminate food and may limit the possible undesirable flavors caused by the direct addition of active compounds to foods. It is also important that packaging is accessible to consumers around the world and, more importantly; must be naturally biodegradable after disposal (Imam et al., 2012).

\section{Methodology}

We used a form for Google search, with area of coverage level Brazil. The criterion for selecting people for the search was by sending the form in bulk with the questions and waiting for the answers. 2,893 people filled in the questionnaire correctly, thus enabling their analysis.

The data were evaluated through the descriptive method, which has as main objective the description of the characteristics of a given population or, therefore, the establishment of relations between variables (Gil, 2010). The approach used in this research was quantitative and qualitative, since it allows to investigate a phenomenon with greater amplitude and depth (Alves-Mazzoti \& Gewandsznajder, 1999).

The number of people analyzed was divided into two groups, A and B, group A being composed of people who did not consider themselves capable of evaluating sustainable packaging and group B who felt able to answer such questioning regarding the purchase decision products with sustainable packaging. Both groups answered the same questions about the type of material they considered to be the most sustainable and also assessed gender, environmental awareness, concerns about the views of 


\section{$2^{\text {nd }}$ International Conference on BUSINESS, MANAGEMENT \& ECONOMICS}

society, positive attitude towards green purchasing and perception of consumer actions, as strong to separate the two groups as well.

\section{Results and Conclusion}

Through the application of a questionnaire to the Brazilian public and the analysis of the researcher, it was possible to observe, firstly, two groups of people; one that has indicated that it does not consider itself capable of evaluating environmentally friendly and sustainable packaging and another that has indicated that sustainable packaging is of value in the choice of product.

\begin{tabular}{|c|c|}
\hline & $\begin{array}{c}\text { PERCENTAGE (\%) OF THE } \\
\text { TOTAL OF INTERVIEWED } \\
\text { PEOPLE }\end{array}$ \\
\hline GROUP A & 79 \\
\hline GROUP B & 21 \\
\hline
\end{tabular}

Table 1. Source: the authors

We also noticed the difference in gender prevalence in the two groups:

\begin{tabular}{|c|c|c|}
\hline & WOMEN (\%) & MEN (\%) \\
\hline GROUP A & 33 & 67 \\
\hline GROUP B & 58 & 42 \\
\hline
\end{tabular}

Table 2. Source: the authors

However, the two groups answered the same questions and in the table below, there were no blank answers. Below you can see the type of packaging material that all consumers consider to be more sustainable, with paper being, in fact, the most recyclable material of all. Although it is worth mentioning that there is already biodegradable plastic material, which would be even more sustainable than paper.

\begin{tabular}{|c|c|}
\hline MATERIAL & \% PEOPLE \\
\hline PAPER & 47 \\
\hline PLASTIC & 23 \\
\hline
\end{tabular}




\begin{tabular}{|c|c|}
\hline METAL & 27 \\
\hline OTHERS & 3 \\
\hline
\end{tabular}

Table 3. Source: the authors

It was observed that the groups behaved in practically opposite ways regarding the questions addressed. This may be due to the fact that the shopper, in view of the gender division perceived at the beginning of the research.

Below you can see how the groups behaved:

\begin{tabular}{|c|c|c|c|c|}
\hline & $\begin{array}{c}\text { ENVIRONMENTAL } \\
\text { AWARENESS }\end{array}$ & $\begin{array}{c}\text { CONCERN } \\
\text { WITH THE } \\
\text { SOCIETY'S } \\
\text { OPINIONS }\end{array}$ & $\begin{array}{c}\text { POSITIVE } \\
\text { ATTITUDE } \\
\text { IN GREEN } \\
\text { PUCHASES }\end{array}$ & $\begin{array}{c}\text { PERCEPTION } \\
\text { OF } \\
\text { CONSUMER } \\
\text { SHARES }\end{array}$ \\
\hline GROUP A & $24 \%$ & $38 \%$ & $25 \%$ & $16 \%$ \\
\hline GROUP B & $76 \%$ & $62 \%$ & $75 \%$ & $84 \%$ \\
\hline
\end{tabular}

Table 4. Source: the authors

Group A, which responded that they did not feel capable of evaluating sustainable packaging, consisted mostly of males, and $76 \%$ of the total was considered to have a good environmental conscience, $38 \%$ said they care about $25 \%$ answered that they have a positive attitude towards green purchasing, that is, try to empirically buy supposedly less industrialized products, and $16 \%$ indicated that they have a good perception of the consumers in general about their importance in the choice of sustainable packaging.

Group B indicated that it considers itself to be environmentally conscious, mostly concerned with the opinions of society about the importance of sustainable packaging and has shown a positive attitude towards green (sustainable) purchases, consequently there is a greater perception of consumers about the sustainable packaging, in view of the global concern with the reduction of impacts of the industry on the environment.

The educational level of the studied public was not researched, because of this, this research has limitations on the detailed analysis of the two groups studied.

\section{References}

Alves-Mazzoti, A. J., \& Gewandsznajder, F. (1999). O método nas ciências naturais e sociais: pesquisa quantitativa e qualitativa. São Paulo: Pioreira. 
Betts, J. A. (2004). Sociedade de consumo e toxicomania: consumir ou não ser. Revista da Associação Psicanalítica de Porto Alegre, 65-81.

Fontoura, A. M., Ogava, C. d., \& Merino, E. A. (2018). A contribuição da gestão de design para a conscientização do consumo responsável como alternativa para o desenvolvimento sustentável. DAPesquisa, 7(9), 510-526.

Gil, A. C. (2010). Como elaborar projetos de pesquisa. São Paulo: Atlas.

Grau, G. R. (2015). Green Restaurants Certification 4.0 Standards. Fonte: Green Restaurants Association University: http://www.dinegreen.com/restaurants/standards.asp

Huang, W., Xu, H., Xue, Y., Huang, R., Deng, H., \& Pan, S. (2012). Layer-by-layer immobilization of lysozyme-chitosan-organic rectorite composites on electrospun nanofibrous mats for pork preservation. Food Research International, 48(2), 784-791.

Imam, S. H., Glenn, G. M., \& Chiellini, E. (2012). Utilization of biobased polymers in food packaging: assessment of materials, production and commercialization. Emerging Food Packaging Technologies, 435-468.

Marsh, K., \& Bugusu, B. (2007). Food packaging—roles, materials, and environmental issues. Journal of food science, 72(3), R39-R55.

Nitschke, J., Altenbach, H.-J., Malolepszy, T., \& Mölleken, H. (2011). A new method for the quantification of chitin and chitosan in edible mushrooms. Carbohydrate Research, 1307-1310.

Nowzari, F., Shábanpour, B., \& Ojagh, S. M. (2013). Comparison of chitosan-gelatin composite and bilayer coating and film effect on the quality of refrigerated rainbow trout. Food Chemistry, 141(3), 1667-1672.

Mohebi E. \& Shahbazi Y. (2017). Application of chitosan and gelatin based active packaging films for peeled shrimp preservation: A novel functional wrapping design. LWT - Food Science and Technology, Vol. 76.

Realini, C. E., \& Marcos, B. (2014). Active and intelligent packaging systems for a modern society. Meat science, 98(3), 404-419. 